\title{
AKTIVITAS ANTIBAKTERI EKSTRAK ETANOL BUAH, DAUN, DAN KULIT BATANG LIMPASU (Baccaurea lanceolata (Miq.) Müll.Arg.) dari KALIMANTAN SELATAN
}

\section{ANTIBACTERIAL ACTIVITY OF EXTRACTS OF FRUITS, LEAVES, AND BARKS OF LIMPASU (Baccaurea lanceolata (Miq.) Müll.Arg.) FROM SOUTH KALIMANTAN}

\author{
Sani Nurlaela Fitriansyah, Yola Desnera Putri, Muhammad Haris, Rival Ferdiansyah, \\ Rita Nurhayati, Yusni Purnama Sari \\ Sekolah Tinggi Farmasi Indonesia \\ Jl. Soekarno Hatta no. 354, Bandung, Indonesia \\ Email: Saninurlaela@stfi.ac.id (Sani Nurlaela Fitriansyah)
}

\begin{abstract}
ABSTRAK
Limpasu merupakan tanaman yang berlimpah dari Kalimantan Selatan. Data empiris menunjukkan buah limpasu berpotensi untuk mengobati demam (karena infeksi), kesehatan kulit, dan antioksidan. Data ilmiah pendukung potensi limpasu sebagai antiinfeksi yang disebabkan bakteri masih minim. Penelitian ini bertujuan mendapatkan data ilmiah kandungan kimia secara kualitatif dan potensi ekstrak limpasu sebagai antibakteri. Bagian buah, daun, dan kulit batang limpasu diekstraksi menggunakan pelarut etanol $96 \%$ dengan soxhlet. Ekstrak cair diuapkan menggunakan rotary evaporator sehingga didapatkan ekstrak buah (EB), ekstrak daun (ED), dan ekstrak kulit batang limpasu (EKB). Pengujian aktivitas antibakteri dilakukan dengan metode difusi padat menggunakan kertas cakram. Bakteri yang diuji terdiri dari Bacillus subtilis, Staphylococcus aureus, Pseudomonas aeruginosa, Escherichia coli, Propionibacterium acnes, dan Staphylococcus epidermidis. Hasil penelitian menunjukkan, ekstrak etanol buah limpasu merupakan ekstrak yang paling aktif terhadap bakteri B. subtilis, S. aureus, $P$. aeruginosa, E.coli, dan $P$. acnes dengan konsentrasi hambat minimum adalah $2,5 \% \mathrm{~b} / \mathrm{v}$ dengan diameter secara berturut-turut 6,87; 7,60; 7,94; 8,80; dan 10,29 mm. Ekstrak etanol buah, daun, dan kulit batang limpasu secara umum positif mengandung alkaloid, flavonoid, tanin, dan saponin.
\end{abstract}

Kata kunci: ekstrak limpasu (Baccaurea lanceolata), aktivitas antibakteri, penapisan fitokimia.

\begin{abstract}
Limpasu is a plenteous plant from South Kalimantan. Empirical data indicated that limpasu fruit was potential to be used for the treatment of fever (due to infection), as well as maintaining skin health and possessing antioxidant properties. There are limited scientific data on the anti-infection activity of this plant. The purpose of this study was to
\end{abstract}


determine the antibacterial activity and qualitatively evaluate the chemical contents of the ethanol extract of limpasu. Extracts of fruits, leaves, and barks of limpasu were obtained by extraction of those plant materials with soxhlet using ethanol $96 \%$. The liquid extract was evaporated by rotary evaporator, until the viscous masses of fruits extract (EB), leaves extract (ED), and barks extract (EKB) were obtained. Antibacterial activity of $E B, E D$, and $E K B$ were evaluated by calculating the minimum inhibitory concentration (MIC) against Bacillus subtilis, Staphylococcus aureus, Pseudomonas aeruginosa, Escherichia coli, Propionibacterium acnes, and Staphylococcus epidermidis. Ethanol extract of fruit limpasu was the most active against $B$. subtilis, $S$. aureus, $P$. aeruginosa, $E$. coli, and $P$. acnes with diameter of inhibitory zones at concentrations of $2.5 \% \mathrm{w} / \mathrm{v}$ were $0.87,7.6,7.94,8.80$, and $10.29 \mathrm{~mm}$, respectively. The ethanol extract of fruits, leaves, and barks of limpasu contained alkaloids, flavonoids, tannins, and saponins.

Key words: limpasu extract, antibacterial activity, phytochemical screening. 


\section{Pendahuluan}

Limpasu (Baccaurea lanceolata (Miq.) Müll.Arg.) merupakan salah satu spesies tanaman berlimpah dari Kalimantan Selatan yang mempunyai data empiris sebagai tanaman obat dari genus Baccaurea. Buah limpasu banyak digunakan salah satunya dalam pengobatan demam dan sakit perut (Noorcahyati dkk., 2010). Demam dapat disebabkan oleh adanya infeksi mikroorganisme terutama bakteri. Telah dilaporkan beberapa spesies dari genus Baccaurea berpotensi sebagai antibakteri. Ekstrak buah Baccaurea angulata berpotensi terhadap bakteri patogen (Momand dkk., 2014). Ekstrak daun Baccaurea courtallensis berpotensi terhadap bakteri Gram positif dan bakteri Gram negatif (Sreelakshmi dkk., 2017). Adanya hubungan kekerabatan dalam suatu tanaman baik genus maupun spesies memungkinkan terdapatnya potensi farmakologi yang sama. Limpasu mempunyai hubungan kekerabatan dalam genus dengan baccaurea angulata dan baccaurea courtallensis.

Potensi farmakologi maupun biologi dari suatu tanaman dapat disebabkan adanya metabolit sekunder. Menurut Bakar dkk. (2014), jika dibandingkan antara kulit buah, daging buah, dan biji buah limpasu, daging buah limpasu mempunyai total fenol yang tertinggi, begitu pula total flavonoid. Sedangkan kulit buah limpasu mempunyai total karotenoid tertinggi. Golongan fenolik dan flavonoid merupakan salah satu kandidat senyawa antibakteri.

Pemilihan metode pengujian aktivitas antibakteri harus murah, terjangkau, dan cocok untuk ekstrak, fraksi, dan isolat (Klancnik dkk., 2010; Aulifa dkk., 2018). Salah satu metode yang dapat digunakan untuk pengujian aktivitas antibakteri untuk ekstrak, fraksi, maupun isolat adalah difusi dan dilusi (Aulifa dkk., 2018).

Penelitian ini bertujuan untuk mengetahui aktivitas antibakteri dari ekstrak etanol limpasu. Bakteri uji yang digunakan terdiri dari Bacillus subtilis, Staphylococcus aureus, Pseudomonas aeruginosa, Escherichia coli, Propionibacterium acnes, dan Staphylococcus epidermidis. Bakteri tersebut merupakan bakteri yang paling umum dan paling sering menginfeksi manusia. 


\section{Metode Penelitian}

Alat dan Bahan

Alat-alat yang digunakan dalam penelitian yaitu: soxhlet, alat-alat gelas kimia, inkubator (Jenaco), autoklaf, spektrofotometer UV-Vis (Shimadzu UVVis 180). Bahan-bahan yang digunakan pada penelitian ini yaitu simplisia buah, daun, dan kulit batang limpasu dari Kalimantan. Bakteri uji yang digunakan adalah bakteri $B$. subtilis, S. aureus, $P$. aeruginosa, E. coli, P. acnes, dan $S$. epidermidis yang didapatkan dari Laboratorium Mikrobiologi, Fakultas Farmasi, Universitas Padjadjaran. Bahan lain adalah DMSO 1\%, akuades steril, etanol $70 \%$, etanol $96 \%$ media nutrient agar, $\mathrm{NaCl} 0,9 \%$, klindamisin fosfat (Medi-Klin), serta bahan kimia lainnya yang digunakan untuk penapisan fitokimia.

\section{Jalannya Penelitian}

\section{Ekstraksi}

Simplisia kering buah, daun, dan kulit batang masing-masing diekstraksi menggunakan soxhlet dengan pelarut etanol 96\%. Penguapan masingmasing ekstrak menggunakan rotary evaporator sehingga didapatkan 3 ekstrak kental yaitu ekstrak buah (EB), ekstrak daun (ED), dan ekstrak kulit batang (EKB).
2. Penapisan fitokimia

Penapisan fitokimia dilakukan terhadap masing-masing ekstrak (EB, ED, dan EKB). Identifikasi kandungan kimia golongan fenol dilakukan dengan menggunakan $\mathrm{FeCl}_{3} 10 \%$, flavonoid menggunakan pereaksi amil alkohol, tanin menggunakan gelatin, alkaloid menggunakan pereaksi Dragendorf dan Mayer, kuinon dengan penambahan $\mathrm{KOH} 5 \%$, saponin dengan adanya pengocokan dan ditunjukkan dengan busa yang konsisten \pm 10 menit dalam ekstrak air, monoterpena dan seskuiterpena menggunakan $10 \%$ vanilin sulfat, steroid dan triterpenoid menggunakan pereaksi LiebermanBurchard (Marliana dkk., 2005).

3. Pengujian aktivitas antibakteri

Masing-masing bakteri uji diremajakan terlebih dahulu pada media nutrient agar yang telah disterilisasi kemudian diinkubasi pada suhu $37^{\circ} \mathrm{C}$ selama $18-24$ jam. Bakteri uji hasil peremajaan masing-masing disuspensikan dalam larutan natrium klorida ( $\mathrm{NaCl}) \quad 0,9 \% \quad b / v \quad$ steril. Suspensi bakteri diukur nilai transmitannya menggunakan spektrofotometer pada panjang 
gelombang $580 \mathrm{~nm}$ hingga diperoleh transmitan $25 \%$.

Pengujian aktivitas antibakteri $E B$, ED, dan EKB menggunakan metode difusi agar. Sebanyak $15 \mathrm{~mL}$ media agar dimasukkan ke dalam cawan petri kemudian didiamkan hingga mengeras, selanjutnya dimasukkan sebanyak $100 \mu \mathrm{L}$ suspensi bakteri ke dalam cawan petri, diratakan dengan spreader pada permukaan media agar dan diinkubasi pada suhu $37{ }^{\circ} \mathrm{C}$ selama 24 jam. Ekstrak dilarutkan dalam DMSO $1 \% \mathrm{v} / \mathrm{v}$ dan dibuat 4 konsentrasi yaitu: $80,60,40$, dan $20 \%$ b/v. Pengujian aktivitas antibakteri dilakukan secara triplo kemudian diukur zona bening dari setiap cawan petri.

Konsentrasi hambat minimum (KHM) EB, ED, dan EKB terhadap keenam bakteri uji ditentukan dengan metode difusi agar menggunakan kertas cakram. Pengujian dilakukan dengan penurunan konsentrasi dari konsentrasi pengujian aktivitas antibakteri, yaitu $10 ; 5 ; 2,5 ; 1,25 \%$, dan $0,625 \%$.

\section{Hasil dan Pembahasan}

Pengujian penapisan fitokimia menunjukkan bahwa EB, ED, dan EKB mengandung senyawa golongan fenol, alkaloid, flavonoid, tannin, dan kuinon (Tabel 1). Golongan fenol dan flavonoid merupakan metabolit sekunder yang terdapat dalam tanaman sebagai kandidat senyawa antioksidan dan antibakteri. Namun demikian, meskipun memiliki kandungan kimia yang sama, kemungkinan EB, ED, dan EKB memiliki jenis dan kadar senyawa yang berbeda. Menurut Bakar dkk. (2014), ekstrak metanol $80 \%$ daging buah limpasu mempunyai total fenol yang tertinggi, begitu pun total flavonoid. Sedangkan kulit buah limpasu mempunyai total karotenoid tertinggi. Selain itu, Bakar dkk. (2014) menunjukkan bahwa ekstrak kulit buah Baccaurea macrocarpa memiliki total fenol dan total flavonoid tertinggi jika dibandingkan dengan ekstrak metanol $80 \%$ daging buah dan biji buah B. macrocarpa. Menurut Aiswarya dkk. (2016), ekstrak metanol daun Baccaurea courtallensis positif terhadap kandungan kimia tanin, saponin, dan fenolik, sedangkan ekstrak metanol buah Baccaurea courtallensis positif terhadap kandungan kimia tanin dan golongan fenolik. 
Tabel 1. Skrining fitokimia

\begin{tabular}{lccc}
\hline \multirow{2}{*}{ Golongan Senyawa } & \multicolumn{3}{c}{ Ekstrak } \\
\cline { 2 - 4 } & Daun & Buah & Kulit Batang \\
\hline Alkaloid & + & + & + \\
Flavonoid & + & + & + \\
Tannin & + & + & + \\
Monoterpen dan Seskuiterpen & - & - & - \\
Steroid dan Terpenoid & - & - & - \\
Kuinon & - & - & - \\
Saponin & + & + & + \\
\hline
\end{tabular}

Metode pengujian aktivitas antibakteri yang digunakan pada penelitian ini adalah metode difusi agar dengan kertas cakram. EB, ED, dan EKB mempunyai potensi sebagai antibakteri baik bakteri Gram positif maupun Gram negatif. Hasil pengujian aktivitas antibakteri terhadap $B$. subtilis, $S$. aureus, $P$. aeruginosa, E. coli, $P$. acnes, dan S. epidermis dapat dilihat pada Gambar 1.

EB merupakan ekstrak yang paling berpotensi sebagai antibakteri terhadap $P$. acnes, $E$. coli, $P$. aureuginosa, S. aureus, dan B. subtilis jika dibandingkan dengan ED dan EKB. Perbedaan potensi tersebut dapat dipengaruhi oleh jenis maupun kadar senyawa kimia yang terkandung dari setiap ekstrak. Aktivitas biologi dan kandungan kimia dapat dipengaruhi oleh faktor fisika maupun kimia (Ngamkitidechakul dkk., 2010). Selain itu adanya perbedaan bagian tumbuhan dan kematangan dari bagian tumbuhan tersebut dapat mempengaruhi aktivitas biologi (Wang dkk., 2003; Duma dkk., 2003).

KHM EB terhadap B. subtilis, $S$. aureus, P. aureuginosa, E. Coli, dan $P$. acnes yaitu 2,5\% b/v. KHM menunjukkan konsentrasi terkecil yang dapat menghambat pertumbuhan bakteri. Toy dkk. (2015), menyatakan bahwa pada metode difusi agar, jika zona hambat suatu ekstrak terhadap bakteri lebih besar dari $6 \mathrm{~mm}$, maka ekstrak tersebut dapat dikatakan mempunyai aktivitas antibakteri. 

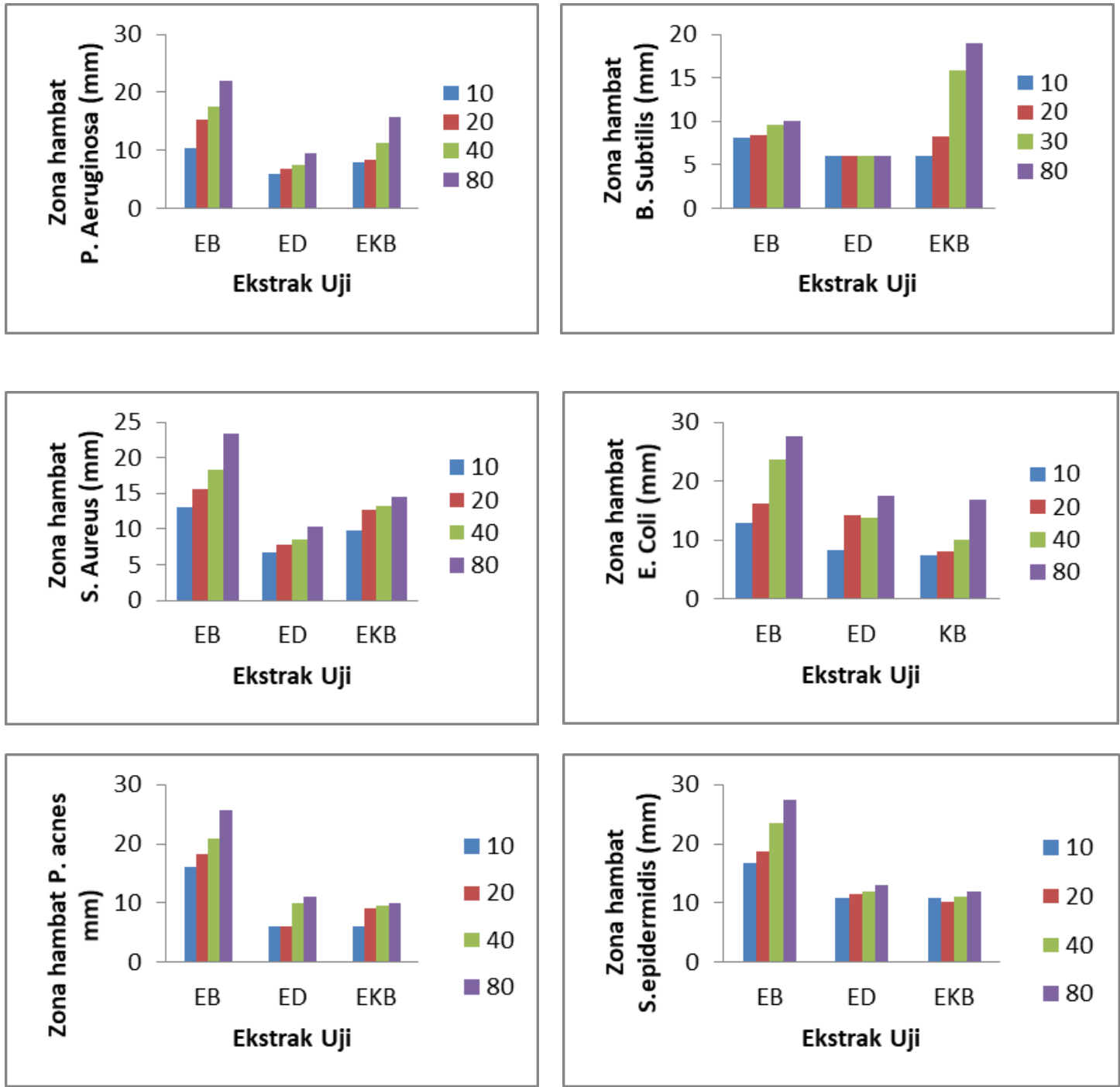

Gambar 1. Hasil uji aktivitas antibakteri ekstrak etanol limpasu konsentrasi 10-80\% (b/v) terhadap bakteri Bacillus subtilis, Staphylococcus aureus, Pseudomonas aeruginosa, Escherichia coli, Propionibacterium acnes, dan Staphylococcus epidermidis. EB, ED, dan EKB menunjukkan berturut-turut ekstrak buah, ekstrak daun, dan ekstrak kulit batang.

\section{Kesimpulan}

Ekstrak etanol buah, daun, dan kulit batang limpasu memilik kandungan kimia golongan alkaloid, fenol, flavonoid, tanin, dan saponin. Ekstrak etanol buah limpasu merupakan ekstrak yang paling aktif terhadap bakteri Gram positif ( $B$. subtilis, S. aureus), bakteri Gram negatif 
(P. aeruginosa, E. coli) dan bakteri penyebab jerawat $P$. acnes dan $S$. epidermidis. Ekstrak etanol daun dan ekstrak etanol kulit batang limpasu relatif kurang aktif terhadap bakteri Gram positif maupun Gram negatif.

Ekstrak etanol buah limpasu mempunyai KHM terhadap $B$. subtilis, $S$. aureus, $P$. aeruginosa, E. Coli, dan $P$. acnes sebesar $2,5 \% \mathrm{~b} / \mathrm{v}$.

\section{Daftar Pustaka}

Aiswarya, K.P., Unnikrishnan, N.S Mahesh, S., and Nair, L.S. 2016. Phytochemical analysis of leaf, bark, and fruit extracts of Baccaurea courtallensis muell. Arg. Journal of Pharmacognosy and Phytochemistry, 5(3):196-198.

Aulifa, D.L., Fitriansyah, S.N., Ardiansyah, S.A., Wibowo, D.P., Julata, Y.A., and Christy, D.S. 2018. Phytochemical screening, antibacterial activity, and mode of action on Morus nigra. Pharmacognosy Journal, 10(1):167-171.

Bakar, A., Ahmad, N.E., Karim, F.A., and Saib, S. 2014. Phytochemicals and antioxidative properties of borneo indigenous liposu (Baccaurea lanceolata) and tampoi (Baccaurea macrocarpa) fruits. Antioxidants, 3:516-525.

Duma, Y., Dadomo, M., Di Lucca G., and Grolier, P. 2003. Effects of environmental factors and agricultural techniques on antioxidant content of tomatoes. Journal of the Science of Food and Agriculture, 83(5):369-382.

Klancnik, A., Piskernik, S., Jeršek, B., and Možina, S.S. Evaluation of diffusion and dilution methods to determine the antibacterial activity of plant extracts. Journal of Microbiological Methods, 81:121-126.

Marliana, S.D., Suryanti, V., and Suyono. 2005. Skrining fitokimia dan analisis kromatografi lapis tipis komponen kimia buah labu siam (Sechium edule Jacq. Swartz.) dalam ekstrak etanol. Biofarmasi, 3(1):26-31.

Momand, L., Ibrahim, M., Zakaria, R., Mikail, M., Jalah, T., and Wahab, R.A. 2014. Antimicrobial effect of Baccaurea angulata fruit extracts against human pathogenic microorganisms. Medicinal \& Aromatic Plants, 3(4):1000172.

Ngamkitidechakul, C., Jaijoy, K., Hansakul, P., Soonthornchareonn, N., and Sireeratawong, S. 2010. Antitumor effects of Phyllantus emblica L.: Induction of cancer cell apoptosis and inhibition of in vivo tumour promotion and in vitro invasion of human cancer cells. Phytotherapy

Research, 24(9):1405-1413.

Noorcahyati, Arifin, Z., dan Ningsih, M.K. 2010. Potensi etnobotani Kalimantan sebagai sumber penghasil tumbuhan berkhasiat obat. Prosiding Seminar Hasil-Hasil Riset untuk Mendukung Konservasi yang Bermanfaat dan Pemanfaatan yang Konservatif. 
Balai Penelitian Teknologi Konservasi Sumberdaya Alam. Samboja.

Sreelakshmi, A.G., Thomas, N., Carla, B., and Sunil, C. 2017. Antihyperlipidemic and antibacterial activities of Baccaurea courtallensis leaves. Journal of Pharmaceutical Research, 1(3):000116.

Toy, T.S., Lampus, B.S., dan Hutagalung, B.S. 2015. Uji daya hambat ekstrak rumput laut Gracilaria sp terhadap pertumbuhan bakteri Staphylococcus aureus. Jurnal eGiGi, 3(1):153-159.

Wang, S.Y., Bunce, J.A., Mass, J. 2003. Elevated carbon dioxide increases content of antioxidant compounds in field-grown strawberries. Journal of Agricultural and Food Chemistry, 51(15):4315-4320 